\title{
SHADOW LANDS, STRANGE LIGHT
}

\section{Charlson Ong}

\section{About the Author}

A distinguished fictionist, Charlson Ong has written three short story collections: Men of the East and other stories, Woman of Amkaw and other stories, and Conversion and other fictions as well as three novels: An Embarrassment of Riches, Banyaga: A Song of War, and Blue Angel/ White Shadow. He teaches creative writing at the University of the Philippines-Diliman. 
For too long the denizens of Muslim Mindanao have remained largely invisible to the mainstream. Popular culture often depicted the Moro as juramentado or armed bandit: inscrutable, dangerous.

In "serious" literature, only a handful like Ibrahim Jubaira, who wrote fiction in English, provided us with an inside tract of the Mindanaoan Muslim for the longest time. Muslims who resided in Christian majority areas tended to downplay their own ethnicities so as to remain inconspicuous.

Open rebellion in the South has significantly altered the mindscape. New Filipino Muslims now tout their religious and cultural identities in various media. Rays of the Invisible Light gathers works from twelve Muslim Filipinos of various descent-Tausug, Meranao, Maguindanao, Iranun and a convert from Manilawho reveal once again the difficulties of being "strangers in a strange land." Not only are they finally different from their Catholic school classmates or colleagues, but they are often alienated as well from conservative kin and co-religionists. "In a world many called sinful/ I found myself in Heaven," writes Sahara Alia Silongan in her poem "Haraam."

Cosmopolitan, well heeled, and university-educated, these young Moro writers can no longer fully abide tradition that allows for multiple wives or slavery, all preIslamic practices. Lorena Halilah Lao's short story "Son of Sugo-on" is a poignant tale of modern-day slavery. On the other hand, Arifah Macacua Jamil's "Sakeenah" and Reinna Bermudez's "Road to Sulgah" plumb the pain of first as well as second wives.

Mohammad Nassefh Macla's poetry speaks once more of the war in Muslim Mindanao even as Kristine Ong Muslim reminds us again that it is the same war raging across much of the Philippine countryside: "Everywhere, the whiff of corn fields/of grains of rice sifted through threshers/of religious lunacy, of superstition/ of tenacity and sweat and violence."

Raised in Manila, Pearlsha Abukar survives the vicissitude of her dual heritage by learning to "hear the heart" and to "play everything by ear" while Datu Shariff Pendatun III tries to rediscover an auspicious, if obscured, past.

Here are glimpses of the Filipino Muslim through the eyes of Moros who have spent a significant part of their lives among non-Muslims, inside the "belly of the beast," as it were. They inhabit the shadow land where the glare of dominant culture is refracted in a prism of contending worldviews. Much of contemporary literature emanates from this place. Many of us must write from dual or multiple ethnicities and cultural backgrounds. In doing so, we can court the displeasure, or worst, of 
those who brook no revaluation of their own values. Alienation from loved ones is perhaps the biggest disincentive to honest writing. "I might turn out to be a bad Muslim if I try now and I know that it will hurt my family," concludes Janesa Mariam Ladjiman in her essay.

Gutierrez Mangasakan II, who put together the collection-the second in a potential series-has spoken elsewhere of the difficulties he encountered in making his own movies that have won international awards. As scion himself of Maguindanaoan royalty, Mangasakan has had to tread the fine line between fact and ancestral lore, truth and "maratabat."

Still in his screenplay excerpted in the book, Mangansakan highlights the survivability of family through the difficult birthing of an heir despite the direst circumstance.

Change is inevitable and a community's ability to adapt underlines its strength. "Unbendingness," notes Saladin Chamcha, in Salman Rushdie's Satanic Verses "can also be monomania, it can be tyranny, and also it can be brittle, whereas what is flexible can also be humane, and strong enough to last."

Finally, the collection reminds us that identity is never done, never finished but always fluid, always in the process of becoming. The survivability of our literature, if not our society, may lie in our willingness to visit the shadow lands on occasion and shine upon it a stranger light. 